\title{
MICROWAVE-ASSISTED SOLVOTHERMAL: AN EFFICIENT AND NEW METHOD TO OBTAIN HYDROPHOBIC WOOD SURFACES
}

\author{
Paula Zanatta ${ }^{1}$, André Luiz Missio ${ }^{2}$, Marilia Lazarotto ${ }^{3}$, Sérgio da Silva Cava ${ }^{1}$, \\ Pedro Lovato Gomes Jardim ${ }^{4}$, Darci Alberto Gatto ${ }^{1, \diamond}$, Mário Lúcio Moreira ${ }^{1,4}$
}

\begin{abstract}
The objective of this work was to form a hydrophobic surface in a highly porous wood by coating and incorporating $\mathrm{TiO}_{2}$ micro/nano structures through the microwave-assisted solvotermal method, without need any pre- or post-modification of the wood substrate, using low temperatures and short times. The behavior and morphology of the $\mathrm{TiO}_{2}$-treated surfaces was characterized using scanning electron microscopy (SEM), while the elemental composition was determined via energy-dispersive $\mathrm{X}$-ray spectroscopy and X-ray diffraction analysis. The results indicated that the crystallization of the $\mathrm{TiO}_{2}$ anatase phase was efficient and fully coated the wood surface during the solvothermal process. The treated wood contained $\mathrm{TiO}_{2}$ particles agglomerate with an average diameter of 200 $\mathrm{nm}$ that also allowed to coat an abundant fraction of tracheids cell walls. When investigated through $\mathrm{X}$-ray spectroscopy-mapping, the element titanium appeared abundantly throughout the wood. After $\mathrm{TiO}_{2}$ growth in wood through the microwave-assisted solvotermal method, a roughness at the micro/ nano scales structures was created on the wood surface, originating an increase in the contact angle up to $137^{\circ}$, which characterizes the appearance of a hydrophobic surface. The $\mathrm{TiO}_{2}$-treated wood demonstrated $85 \%$ of water absorption after $400 \mathrm{~h}$ of immersion, while untreated wood reached $160 \%$, suggesting that the microwave-assisted solvotermal process promotes a delay in the progression of water absorption. This feature can improve the dimensional stability of wood, contributing to the increase of its durability and applications.
\end{abstract}

Keywords: Nanoparticles, Pinus elliotti, wettability, wood modification, wood technology.

\section{INTRODUCTION}

The hydrophilic nature of the polymers (cellulose, hemicellulose and lignin) constituting wood cell wall results in a material sensitive to moisture, mainly when exposed to environmental conditions. These polymers contain groups $\mathrm{OH}$ and oxygen in their chains that attract water through means of hydrogen bonds (Evans et al. 2000, Sedighi-Moghaddam 2015). Another cause for water affinity is the presence of porous structures, as the tracheids in the case of conifers, that provide wide circulation of liquids (Jia et al. 2016).

${ }^{1}$ CCAF, Engenharia de Materiais (PPGCEM) Centro de Desenvolvimento Tecnológico, Universidade Federal de Pelotas, RS, Brasil.

${ }^{2}$ Laboratório de Produtos Florestais (PPGEF), Centro de Ciências Rurais, Universidade Federal de Santa Maria, Santa Maria, RS, Brasil.

${ }^{3}$ Faculdade de Agronomia, Departamento de Horticultura e Floricultura, Universidade Federal do Rio Grande do Sul, Porto Alegre, RS Brasil.

${ }^{4} \mathrm{CCAF}$, Instituto de Física e Matemática, Departamento de Física, Universidade Federal de Pelotas, RS, Brasil.

"Corresponding author: darcigatto@pq.cnpq.br

Received: 08.05.2017 Accepted: 06.05.2018 
These conditions lead to volumetric changes in the wood structure and induces tensions in the cell wall, causing deformations such as warping and cracking (Sun et al. 2010, Zheng et al. 2015). In addition, water absorption favors the proliferation of fungi, since they require moisture to develop. This feature compromises the use and durability of the wood and limits wood samples applications in humid conditions.

Therefore, it is necessary the implementation of protective agents to avoid water absorption in wood cell wall. Currently, many approaches using surface treatment, have been reported and developed to minimize the effects of water wood absorption, for example, with waxes, cold plasma and ceramics (Lesar and Humar 2011, Sun et al. 2012, Wang et al. 2012, Liu et al. 2015, Zheng et al. 2015, Cademartori et al. 2016, Jia et al. 2016).

Inspired on lotus leaves, which have high capacity to repel water, the creation of a hydrophobic surface becomes a promising approach in order to optimize the implementation of wood in several environments with different moisture contents. Artificial hydrophobic surfaces are manufactured by the combination of chemical composition, morphology and roughness of surface coatings (Zhang et al. 2008).

Some ceramic nanoparticles such as $\mathrm{TiO}_{2}, \mathrm{ZnO}$ and $\mathrm{SiO}$, were used for wood modification and have great potential in the development of diverse surfaces with suitable wettability for different conditions. These compounds showed good efficiency in converting hydrophilic $\mathrm{OH}$ groups in hydrophobic surfaces (Liu et al. 2015, Lu and Hu 2016). Among others, some of the methodologies reported for wood modification and creating hydrophobic surfaces are sol-gel processes (Lu et al. 2014) hydrothermal processes (Gao et al. 2015), depositions at room temperature (Zheng et al. 2015), coating processes (Rassam et al. 2012) and of impregnation by pressure (Zanatta et al. 2017).

The development of faster and more environment friendly procedures is essential to the current scenario. In this sense, the microwave-assisted solvothermal (MAS) method, widely used for nanoparticles synthesis (Moura et al. 2014, Wang et al. 2015), rarely reported for wood modification. This method becomes attractive to coat, grow and impregnate inorganic materials on the surface and inside the wood tracheids, as it is simple, with few steps, and present reduced synthesis time and temperature (Diebold 2003). $\mathrm{TiO}_{2}$ can be easily obtained by MAS and it has been greatly used to prepare rugged and self-cleaning surfaces with high hydrophobicity (Liu et al. 2015, Huang et al. 2000). $\mathrm{TiO}_{2}$ is currently one of most widely used multifunctional nano-materials, it is a polymorph with low toxicity which crystalizes under three distinct structures: anatase (tetragonal), rutile (tetragonal) and brookite (orthorhombic), being the anatase the most interesting structure due to its photoactivity and typical grain size (Lee et al. 2010).

In this context, the objective of this work was to form a hydrophobic surface in a highly porous wood by coating and incorporating $\mathrm{TiO}_{2}$ particles through the microwave-assisted solvothermal method, without need any pre- or post- modification of the wood substrate. Accordingly, this paper presents studies of (i) preparation of $\mathrm{TiO}_{2}$ particles through titanium isopropoxide and (ii) wood modification with $\mathrm{TiO}_{2}$ micro/nano structures and its characterization. Finally, the behavior and morphology of the $\mathrm{TiO}_{2}$-treated wood was observed. The results of this study reveal the possibility for wood modifications and hydrophobic surface formation able to delay the absorption of water, which contributes to the formation of woods more resistant to moisture and durable.

\section{MATERIALS AND METHODS}

\section{Materials}

The Pinus elliottii wood used in the study was provided by reforestation in southern Brazil, more precisely in the Pelotas city region. The size used for the samples was $10 \times 10 \times 10 \mathrm{~mm}$, stabilized at $12 \%$ of moisture. All the samples were prepared from the first $\log (3 \mathrm{~m}$ in length from the base of the trees), avoiding defects in the samples (Missio et al. 2016). For the $\mathrm{TiO}_{2}$ growth were employed titanium isopropoxide $\left(\mathrm{Ti}\left[\mathrm{OCH}\left(\mathrm{CH}_{3}\right)_{2}\right]_{4}\right)$ at $97 \%$ purity and ethyl alcohol $\left(\mathrm{C}_{2} \mathrm{H}_{6} \mathrm{O}\right) 95 \%$, obtained 
from Sigma-Aldrich and Synth, respectively.

\section{Synthesis of $\mathrm{TiO}_{2}$ and wood modification}

The MAS method was used for wood modification. To crystallizes the $\mathrm{TiO}_{2}$ on and inside the wood, an alcoholic solution of $30 \mathrm{~mL}$ was stirred with $0,07 \mathrm{~mol}^{-1}$ of titanium isopropoxide and ethyl alcohol. Subsequently the $P$. elliottii samples were added to the solution, which remained under constant stirring and nitrogen flow for 10 minutes. The solution with wood samples was transferred to teflon reaction cell and then coupled to the microwave system. After reaching $140^{\circ} \mathrm{C}$ at heating rate of $6^{\circ} \mathrm{C} /$ minute, the surface modification of the wood occurred for 60 minutes at this temperature. Finally, the wood samples were dried at $100^{\circ} \mathrm{C}$ for $24 \mathrm{~h}$. In order to verify that only $\mathrm{TiO}_{2}$ was formed, the same procedure was performed without the addition of wood samples.

\section{Characterization}

\section{Structural and morphological analysis}

By X-ray Diffraction (XRD) was verified the presence of $\mathrm{TiO}_{2}$ in the wood samples. This characterization was performed by a Rigaku diffractometer with Bruker rotating anode, model D8 Advance, using $\mathrm{Cu} \mathrm{K} \alpha 1(\lambda=1,5406 \AA)$ and $\mathrm{Cu} \mathrm{K} \alpha 2(\lambda=1,5406 \AA)$ radiations, at $40 \mathrm{kV}$ and 150 $\mathrm{mA}$ in a range of $10^{\circ}-90^{\circ}$. By Scanning Electron Microscope (SEM) (JEOL JSM - 6610LV) under high vacuum, at $15,00 \mathrm{kV}$, the coating and the impregnation of the wood surface and tracheids were evaluated. Energy-dispersive X-ray Spectroscopy (EDX), coupled with SEM, was performed to verify the chemical composition of the samples.

\section{Hydrophobicity and liquid water uptake}

The hydrophobicity of the untreated and wood- $\mathrm{TiO}_{2}$ samples was evaluated by measuring the static contact angle at six different times: 5, 20, 35, 50, 65 and 80 seconds after the contact of the droplet ( $20 \mu 1$ of deionized water) on the sample surface. It was used a Drop Shape Analyzer goniometer, model DSA25, configured for the sessile drop method. In order to verify the influence of the MAS process on the surface of the wood, the wettability test was carried out on samples of wood that underwent the solvothermalization, without the titanium precursor.

The water absorption was measured by the immersion of the samples (at $12 \%$ of moisture content) in deionized water for a period of $400 \mathrm{~h}$. There were five replicates. Periodically, the weight of each sample was collected with an analytical balance. The percentage of weight change, as per Equation 1, was used determine the water uptake of wood.

$$
\Delta W(\%)=\left[\frac{W_{1}-W_{0}}{W_{0}}\right] x 100
$$

Where: $\Delta \mathrm{W}=$ weight variation; $\mathrm{W}_{0}=$ weight of the sample before the immersion ( $12 \%$ moisture) $(\mathrm{g}) ; \mathrm{W}_{1}=$ weight of the sample after the immersion $(\mathrm{g})$.

\section{RESULTS AND DISCUSSION}

\section{Structural and morphological analysis}

Before the wood modification process, the $\mathrm{TiO}_{2}$ structure was firstly investigated. After applying for $60 \mathrm{~min}$ the MAS process over the precursor solution of titanium isopropoxide and ethyl alcohol, a white precipitated powder was obtained and it was characterized by XRD and SEM. The XRD pattern showed the peaks relate to pure anatase phase (JCPDS File 21-1272), as shown in Figure 1a. This is a very important result because the anatase $\mathrm{TiO}_{2}$ phase is normally found associated to an amount 
of rutile phase. Additionally, SEM images show that the particle agglomerates had roughly spherical shape with an average size of $200 \mathrm{~nm}$.

Being able to produce $\mathrm{TiO}_{2}$ through the MAS method, a new methodology for wood modification was developed. Unlike the XRD of untreated wood (Figure 1b), the crystalline structure of the treated wood obtained by MAS method indicated that the wood was dominated by $\mathrm{TiO}_{2}$ anatase phase (Figure $1 \mathrm{c}$ ), indexed by the peaks at $24^{\circ}, 37,8^{\circ} ; 48,3^{\circ} ; 53^{\circ}$ and $74,9^{\circ}$ while only the peak at $45^{\circ}$ corresponds to the rutile phase (JCPDS file 21-1276). The rutile phase can be found in the treated wood because its formation is favored in acidic conditions, as the $\mathrm{pH}$ of the reaction medium dropped with the addition of the samples to the solution (Mourão et al. 2009). It was noted that the combined action of the solvent, microwave radiations, as well as the acidity of the solution might have modified the crystalline planes of cellulose. The maximum intensity of crystalline cellulose fraction (002) is identified by the peak at $22,5^{\circ}$, which decrease in the $\mathrm{TiO}_{2}$-treated wood. This may be the result of the MAS process, affecting the hydrogen bonds of the crystalline portion of the cellulose (El Oudiani et al. 2011, Perrone 2015). This intensity decrease occurred in combination with changes in the cellulose shape. In other words, the changing in cellulose unit cell parameters can explain the increased in intensity of the peak at $34,8^{\circ}$, representing the crystallographic plane (040) of type I cellulose.

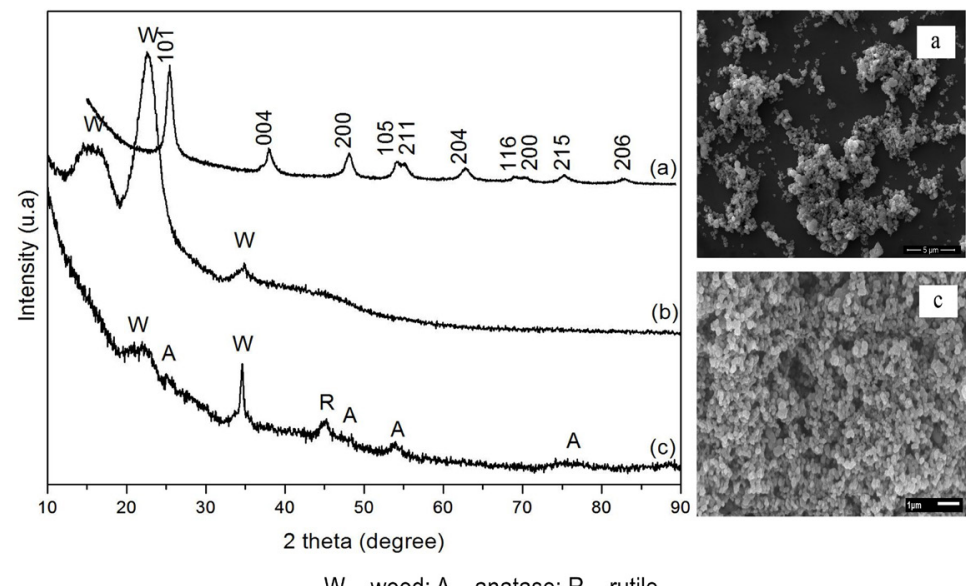

Figure 1: XRD and SEM of the (a) $\mathrm{TiO}_{2}$ nanoparticles, (b) natural wood and (c) $\mathrm{TiO}_{2}$-treated wood surfaces synthesized by the MAS method.

The appearance of the surface and the anatomical structures of coniferous wood is well described in previous studies (Wimmer 2002, Siegloch and Marchiori 2015). It is known that the surface is rough (Figure 2a) and it is characterized by pores (tracheids) in the micrometer order, with a diameter greater than 10 micrometers (Figure 2c), which lead to its high porosity. So, naturally, a drop of water is absorbed quickly by tracheids, entering the interfaces of the cell wall (volume change) and filling the lumen (weight change), attributing its hydrophilic character. This condition limits its use to decks, external structures, openings, garden furniture, frames, as it favors the impregnation or modification by other materials or products.

Due to the micrometric size of tracheids, it is not expected that the treated wood presents totally clogged pores with $\mathrm{TiO}_{2}$ particles. However, to avoid the liquid absorption, it is necessary to employ the hydrophobic features of $\mathrm{TiO}_{2}$ anatase phase deposited on the surface (Figure $2 \mathrm{~b}$ ) and inside (Figure 2d) the wood. $\mathrm{TiO}_{2}$ was crystallized in the cell wall, inside the lumen and on the surface of the wood, and $\mathrm{TiO}_{2}$ spheres were distributed uniformly on the surface of the wood. In some places, there was a continuous coating on and in the wood, including pits (Figure 2e) and rains (Figure 2f), in the longitudinal section. The roughness obtained from the formation process of the wood modification, both on the surface and in the cell wall of the wood, ranged from micro to nanoscale, resembling the hydrophobic hierarchical surface characteristics found in nature. 

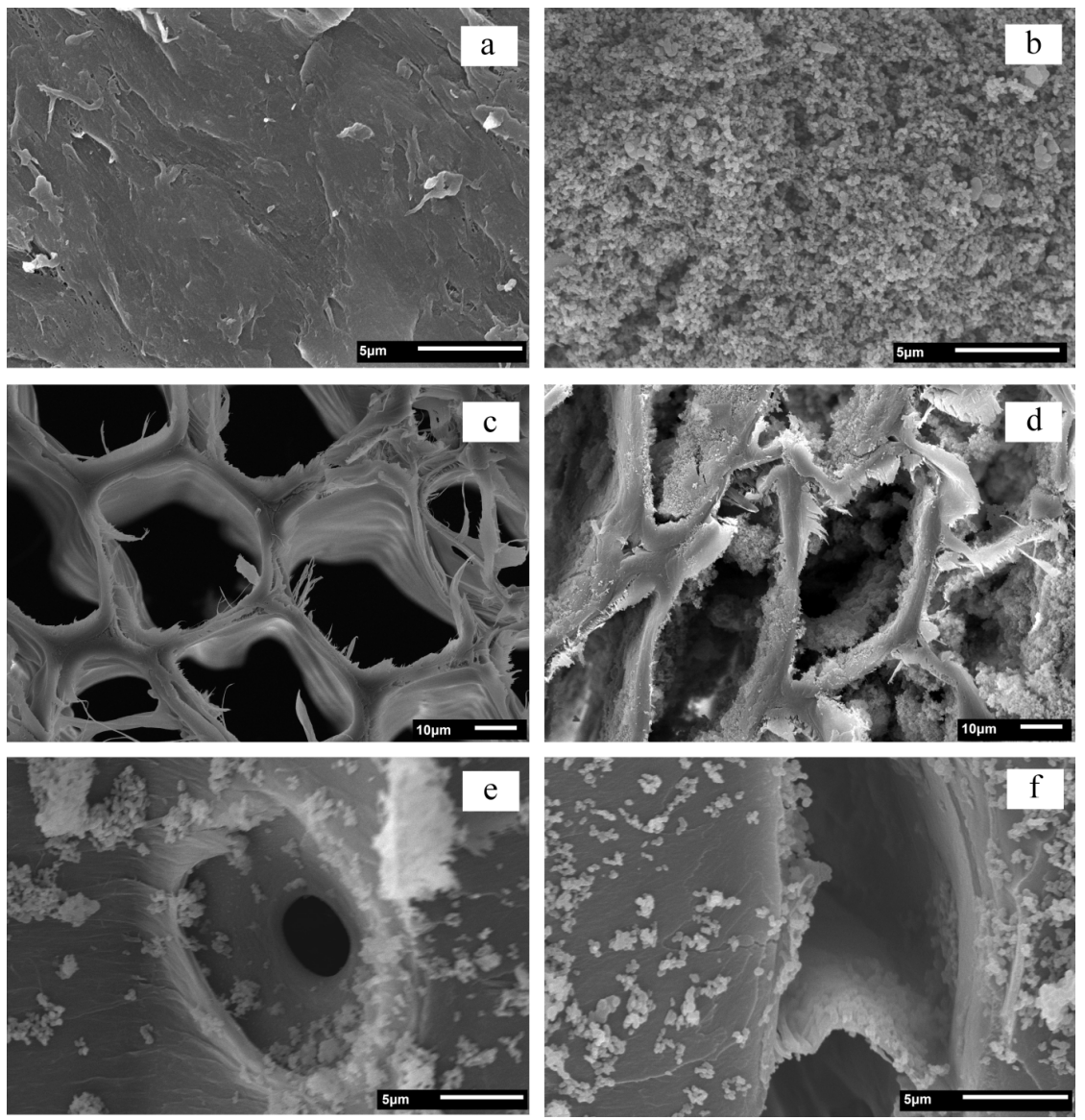

Figure 2: SEM images of the natural wood and the $\mathrm{TiO}_{2}$-treated wood. (a) natural wood surface; (b) $\mathrm{TiO}_{2}$-treated wood surface; (c) pores of the natural wood; (d) $\mathrm{TiO}_{2}$-treated wood pores; (e) and (f) $\mathrm{TiO}_{2}$ interaction with structures present in the wood (pits and rains).

SEM-EDX cross-section images of the samples demonstrates that the surface was entirely coated by $\mathrm{TiO}_{2}$ (Figure $3 \mathrm{~b}$ ) as observed in Figure $2 \mathrm{~b}$; inside the tracheids, the coating is not so efficient, as demonstrate in Figures 2e and f. In any way this cannot be a limiting factor, once it is flagrant the contribution of $\mathrm{TiO}_{2}$ on the wood surface compared to the untreated wood, which primarily presents Carbon $(\mathrm{C})$, Oxygen $(\mathrm{O})$ and Nitrogen $(\mathrm{N})$ (Figure 3a). In some areas of the SEM images, it is not possible to verify the presence of $\mathrm{TiO}_{2}$ nanoparticles inside the cell wall of tracheids. However, when investigating through EDX-mapping, it was noticed that even in the longitudinal section, where there was no direct contact with the precursor solution, the element titanium appeared abundantly throughout the wood (Figure $3 \mathrm{~b}$, i, ii). This may suggest that the titanium, in addition to the coat, fills the micro spaces inside the cell wall. For this reason, it may be expected that the properties of the $\mathrm{TiO}_{2}$-treated wood are differentiated, when compared with the natural wood. 

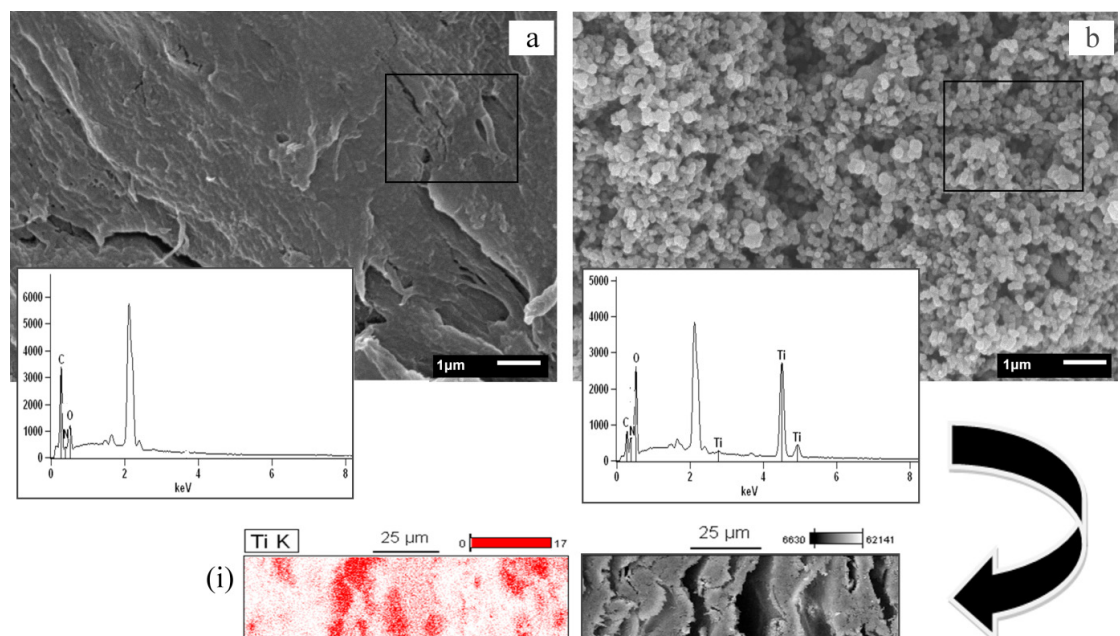

(i)

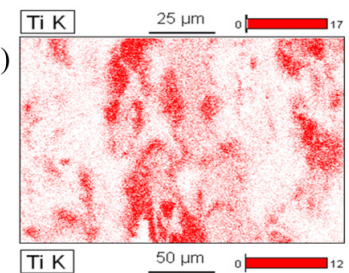

(ii)
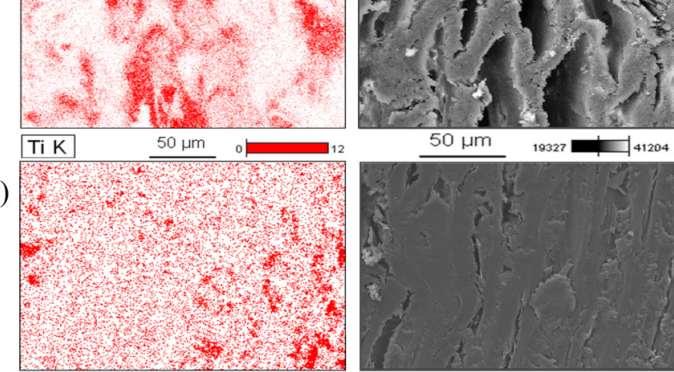

Figure 3: SEM-EDX chemical composition of the (a) natural wood and (b) $\mathrm{TiO}_{2}$-treated wood. The titanium X-ray mapping of the (i) cross and (ii) tangential section of the $\mathrm{TiO}_{2}$-treated wood.

\section{Hydrophobicity}

The polymers (cellulose, hemicellulose and lignin) of the wood contain numerous hydrophilic groups which absorb water and, in the case of pine wood, also there are large cavities that facilitate fluid circulation and storage. Besides, after it penetrates into these cavities, water is quickly absorbed by the cell wall of the tracheids. In order to avoid water penetration into the tracheids, $\mathrm{TiO}_{2}$ crystallization on the surface of wood can supply a hydrophobic character to treated wood. The wettability analysis to assess the $\mathrm{TiO}_{2}$ efficiency in this process was made at the cross section, because it is the part that presents greater water absorption in relation to the other sections. Figure 4 shows the evolution of static contact angle of the water droplet on the wood surface (cross section of tracheids) as a function of time.

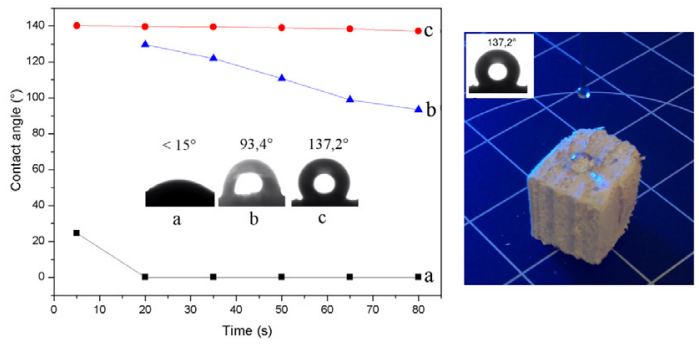

Figure 4: Contact angle evolution against time for the (a) natural wood (b) wood exposed to MAS conditions and (c) $\mathrm{TiO}_{2}$-treated wood. 
The initial contact angle measured for untreated wood was very low, less than $26^{\circ}$, and water was completely absorbed in $20 \mathrm{~s}$. When the MAS process was employed over wood, without the titanium precursor during the solvothermalization, the initial contact angle increases up to $125^{\circ}$ and it was associated to a delayed water absorption (Figure 4) due to obstruction of the cavities. A final contact angle of $93,4^{\circ}$ was reached $80 \mathrm{~s}$ after the addition of the water drop on the wood surface, indicating less water absorption and spreading compared to untreated wood.

After $\mathrm{TiO}_{2}$ growth in wood through the MAS method, the coating created on the surface of wood changed the topographic characteristics of surface, adding a roughness in nano/micrometric scale and the contact angle increases to $137^{\circ}$, which characterizes the appearance of hydrophobic surface, with the surface area of the wood increases with the addition of these structures. In addition to modifying the surface of the wood, there is the possibility that the $\mathrm{TiO}_{2}$ particles deposited on the substrate inactivate some $\mathrm{OH}^{-}$groups present in the polymers of the wood cell wall. Another important aspect associated to the hydrophobicity increase is the high stability of the contact angle through a long time (Figure 4). This stability of the water droplet shows that the decrease of the contact angle in treated wood is not influenced by the evaporation of the droplet, but only by the high hygroscopicity of the wood.

It is important to mention that there are reports of hydrophobic surfaces through wood surface modification with metal oxides (Zheng et al. 2015, Liu et al. 2015). However, the great advantage of this work is that the method used does not require previous treatment or functionalization of the nanoparticles. Furthermore, the manufacturing of this surface is obtained in a short period of time, with one step and do not use expensive and toxic chemical reactants in the process.

\section{Liquid water uptake}

Figure 5 shows the evolution of the wood water absorption during $400 \mathrm{~h}$ of immersion, where it is clear the decrease of the water absorption for $\mathrm{TiO}_{2}$-treated wood, when compared to the untreated material. Untreated and $\mathrm{TiO}_{2}$-treated wood reached a steady state in approximately $160 \mathrm{~h}$. The weight variation in this period is due to the absorption of water in the lumen and/or cell wall of the wood. The weight variation of $\mathrm{TiO}_{2}$-treated wood reached $85 \%$ after $400 \mathrm{~h}$ of immersion, while the untreated samples reached $160 \%$. The treated wood by MAS process delayed the absorption of water, due to the presence of $\mathrm{TiO}_{2}$ and the Ti element prevented water adsorption in the empty spaces of the cell wall. This allows greater dimensional stability. After $400 \mathrm{~h}$ of immersion the samples did not show great color variation or turbidity, which makes believe that there was low leaching of $\mathrm{TiO}_{2}$ nanoparticles. This indicates a strong and stable attachment of the $\mathrm{TiO}_{2}$-coating to the wood surface and may be occurring through hydrogen bonds between the particles and the $\mathrm{OH}^{-}$groups present in the polymeric groups of the wood (Wang et al. 2014).

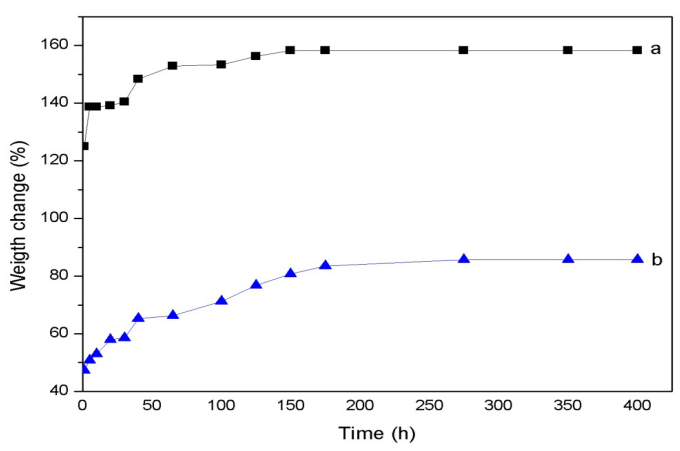

Figure 5: Variation of the weight percentage of the (a) natural wood and of the (b) $\mathrm{TiO}_{2}$-treated wood during $400 \mathrm{~h}$ of immersion in water. 


\section{CONCLUSIONS}

In the present study, the MAS new process proved to be efficient in modifying wood with inorganic materials, producing composite based on wood and $\mathrm{TiO}_{2}$. This treatment was performed at low temperatures and for a short time, without the need for additional treatments. The hierarchical structures of $\mathrm{TiO}_{2}$ anatase phase were visualized on the surface and on the cell wall of the wood. The chemical element $\mathrm{Ti}$ was mapped in the empty spaces of the cell wall, indicating good impregnation and distribution of the precursor solution in the wood matrix. During the process, the structures of $\mathrm{TiO}_{2}$ created a coating on the wood surface, reducing the free surface energy. This led to the formation of macro, micro and nanometric structures on the surface of the $\mathrm{TiO}_{2}$-treated wood, changing to hydrophobic the original hydrophilic surface. In addition, the water absorption of the modified wood was lower in compared to the untreated wood. Therefore, the MAS process is promising for wood modification and provides a pathway for the formation of woods more resistant to moisture, expanding its applications.

\section{AKNOWLEDGEMENTS}

The authors would like to thank the Center of Electronic Microscopy of the Federal University of Rio Grande. This work was supported by The Brazilian National Council for Scientific and Technological Development (CNPq: 471550/2013-2) and Coordination for the Improvement of Higher Education Personnel - Brazil (Capes). The authors declare that they have no conflict of interest.

\section{REFERENCES}

Cademartori, P. H. G.; Nisgoski, S.; Magalhães, W. L.; De Muniz, G. I. B. 2016. Surface wettability of Brazilian tropical wood flooring treated with He plasma. Maderas-Cienc Tecnol 18 (4): 715-722.

Diebold, U. 2003. The surface science of titanium dioxide. Surface Science Reports 48 (5): 53-229.

El Oudiani, A.; Chaabouni, Y.; Msahli, S.; Sakli, F. 2011. Crystal transition from cellulose I to cellulose II in $\mathrm{NaOH}$ treated Agave americana L. fibre. Carbohydrate Polymers 86 (3): 1221-1229.

Evans, P. D.; Wallis, A. F. A.; Owen, N. L. 2000. Weathering of chemically modified wood surfaces. Wood Science and Technology 34 (2): 151-165.

Gao, L.; Zhan, X.; Lu, Y.; Li, J.; Sun, Q. 2015. pH-dependent structure and wettability of $\mathrm{TiO}_{2}$ based wood surface. Materials Letters 142: 217-220.

Huang, Z.; Maness, P. C.; Blake, D. M.; Wolfrum, E. J.; Smolinski, S. L.; Jacoby, W. A. 2000. Bactericidal mode of titanium dioxide photocatalysis. Journal of Photochemistry and Photobiology A: Chemistry 130 (2): 163-170.

Jia, S.; Liu, M.; Wu, Y.; Luo, S.; Qing, Y.; Chen, H. 2016. Facile and scalable preparation of highly wear-resistance superhydrophobic surface on wood substrates using silica nanoparticles modified by VTES. Applied Surface Science 386: 115-124. 
Lee, S.; Cho, I.S.; Noh, J.H.; Hong, K.S.; Han, G.S.; Jung, H.S.; Shin, H. 2010. Correlation of anatase particle size with photocatalytic properties. Physica Status Solidi (a) 207 (10): 2288-2291.

Lesar, B.; Humar, M. 2011. Use of wax emulsions for improvement of wood durability and sorption properties. European Journal of Wood and Wood Products 69 (2): 231-238.

Liu, M.; Qing, Y.; Wu, Y.; Liang, J.; Luo, S. 2015. Facile fabrication of superhydrophobic surfaces on wood substrates via a one-step hydrothermal process. Applied Surface Science 330: 332338.

Lu, X.; Hu, Y. 2016. Layer-by-layer deposition of $\mathrm{TiO}_{2}$ nanoparticles in the wood surface and its superhydrophobic performance. BioResources 11 (2): 4605-4620.

Lu, Y.; Feng, M.; Zhan, H. 2014. Preparation of $\mathrm{SiO}_{2}-$ wood composites by an ultrasonic-assisted sol-gel technique. Cellulose 21 (6): 4393-4403.

Missio, A. L.; de Cademartori, P. H. G.; Mattos, B. D.; Santini, E. J.; Haselein, C. R.; Gatto, D. A. 2016. Physical and Mechanical Properties of Fast-Growing Wood Subjected to Freeze-Heat Treatments. BioResources 11 (4): 10378-10390.

Moura, K. F.; Maul, J.; Albuquerque, A.R.; Casali, G.P.; Longo, E.; Keyson, D.; Santos, I.M.G. 2014. $\mathrm{TiO}_{2}$ synthesized by microwave assisted solvothermal method: Experimental and theoretical evaluation. Journal of Solid State Chemistry 210 (1): 171-177.

Mourão, H. A. J. L.; Mendonça, V.D.; Malagutti, A. R.; Ribeiro, C. 2009. Nanoestruturas em fotocatálise: uma revisão sobre estratégias de síntese de fotocatalisadores em escala nanométrica. Química Nova 32 (8): 2181-2190.

Perrone, O. M. 2015. Avaliação térmica e estrutural do bagaço de cana de açúcar pré tratado com ozônio, ultrassom e micro-ondas para produção de etanol celulósico por hidrólise enzimática. [online] available: <http://repositorio.unesp.br/handle/11449/127894> [accessed 02.12.2016].

Rassam, G.; Abdi, Y.; Abdi, A. 2012. Deposition of $\mathrm{TiO}_{2}$ nano-particles on wood surfaces for UV and moisture protection. Journal of Experimental Nanoscience 7 (4): 468-476.

Sedighi-Moghaddam, M. 2015. Wettability of modified wood. Doctoral Dissertation, KTH Royal Institute of Technology.

Siegloch, A.M.; Marchiori, J.N.C. 2015. Anatomia da madeira de treze espécies de coníferas. Revista Ciência da Madeira 6 (3): 149-165.

Sun, Q.; Lu, Y.; Zhang, H.; Zhao, H.; Yu, H.; Xu, J.; Liu, Y. 2012. Hydrothermal fabrication of rutile $\mathrm{TiO}_{2}$ submicrospheres on wood surface: an efficient method to prepare UV-protective wood. Materials Chemistry and Physics 133 (1): 253-258.

Sun, Q.; Yu, H.; Liu, Y.; Li, J.; Lu, Y.; Hunt, J. F. 2010. Improvement of water resistance and dimensional stability of wood through titanium dioxide coating. Holzforschung 64 (6): 757-761.

Wang, B.; Feng, M.; Zhan, H. 2014. Improvement of wood properties by impregnation with $\mathrm{TiO}_{2}$ via ultrasonic-assisted sol-gel process. RSC Advances 4 (99): 56355-56360.

Wang, X.; Liu, J.; Chai, Y. 2012. Thermal, mechanical, and moisture absorption properties of wood- $\mathrm{TiO}_{2}$ composites prepared by a sol-gel process. BioResources 7 (1): 0893-0901.

Wang, X.; Tian, J.; Fei, C.; LV, L.; Wang, Y.; Cao, G. 2015. Rapid construction of $\mathrm{TiO}_{2}$ aggregates using microwave assisted synthesis and its application for dye-sensitized solar cells. RSC Advances 5 (12): 8622-8629.

Wimmer, R. 2002. Wood anatomical features in tree-rings as indicators of environmental change. Dendrochronologia 20 (1-2): 21-36. 
Zanatta, P.; Lazarotto, M.; Gonzalez De Cademartori, P. H.; Cava, S. D. S.; Moreira, M. L.; Gatto, D. A. 2017. The effect of titanium dioxide nanoparticles obtained by microwave-assisted hydrothermal method on the color and decay resistance of pinewood. Maderas-Cienc Tecnol 19 (4): 495-506.

Zhang, X.; Shi, F.; Niu, J.; Jiang, Y.; Wang, Z. 2008. Superhydrophobic surfaces: from structural control to functional application. Journal of Materials Chemistry 18 (6): 621-633.

Zheng, R.; Tshabalala, M. A.; LI, Q.; Wang, H. 2015. Construction of hydrophobic wood surfaces by room temperature deposition of rutile $\left(\mathrm{TiO}_{2}\right)$ nanostructures. Applied Surface Science 328: 453-458. 